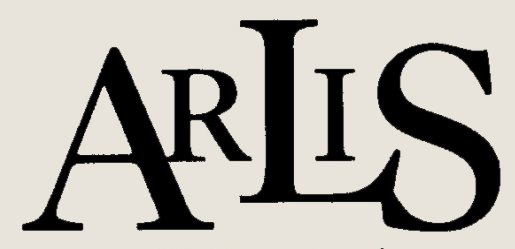

UK \& Ireland

Art Libraries Society

\title{
Trade Literature
}

\section{Cataloguing and Classification Guidelines}

\section{Compiled by \\ Bernadette Archer and Kaye Bagshaw \\ for the}

ARLIS/UK \& Ireland Cataloguing and Classification Committee

\section{4}

\section{ISBN 0951967487}

These guidelines are designed for anyone whose collections include trade literature, both current and historic. They provide general guidance on cataloguing and classifying these ephemeral resources, including: defining trade literature, constructing minimal level catalogue records, examples of full catalogue records in MARC21 format and an introduction to classification schemes commonly used for this material. The cataloguing section expands on and supplements AACR2, providing many examples of trade literature, in a variety of formats. Available in CD-ROM format, the guidelines also provide links to key resources on the Web useful for the cataloguing and classification of trade literature.

> Price: $£ 20$ for ARLIS/UK \& Ireland members; £25 for non-members

$>$ Format: CD-ROM

$>$ Publication date: 2004

All orders and correspondence should be sent to:

ARLIS/UK \& Ireland, Administrator; The Courtauld Institute of Art, University of London, Somerset House, The Strand, London, WC2R ORN, UK Tel:+44(0) 2078482703 Fax:+44 (0) 2078482887 Email:arlis@courtauld.ac.uk Cheques should be made payable to ARLIS/UK \& Ireland and payment should be made in pounds sterling or US dollars. 


\section{Design and Applied Arts Index (DAAI)}

\section{0,000-12,000 RECORDS / YEAR - UPDATED 9 TIMES A YEAR • BACKFILES TO 1973}

\section{Now published by CSA}

\section{Design and Applied Arts}

Index (daai) is the main bibliographic source for current material and information in the areas of design and the applied arts worldwide. As the market leader, it is an indispensable resource for researchers, students, and librarians in the field, as well as for active designers and artists.

daai covers more than 500 international design and craft journals published since 1973, and contains data on almost 55,000 designers, craftspeople, studios, workshops, firms, etc.

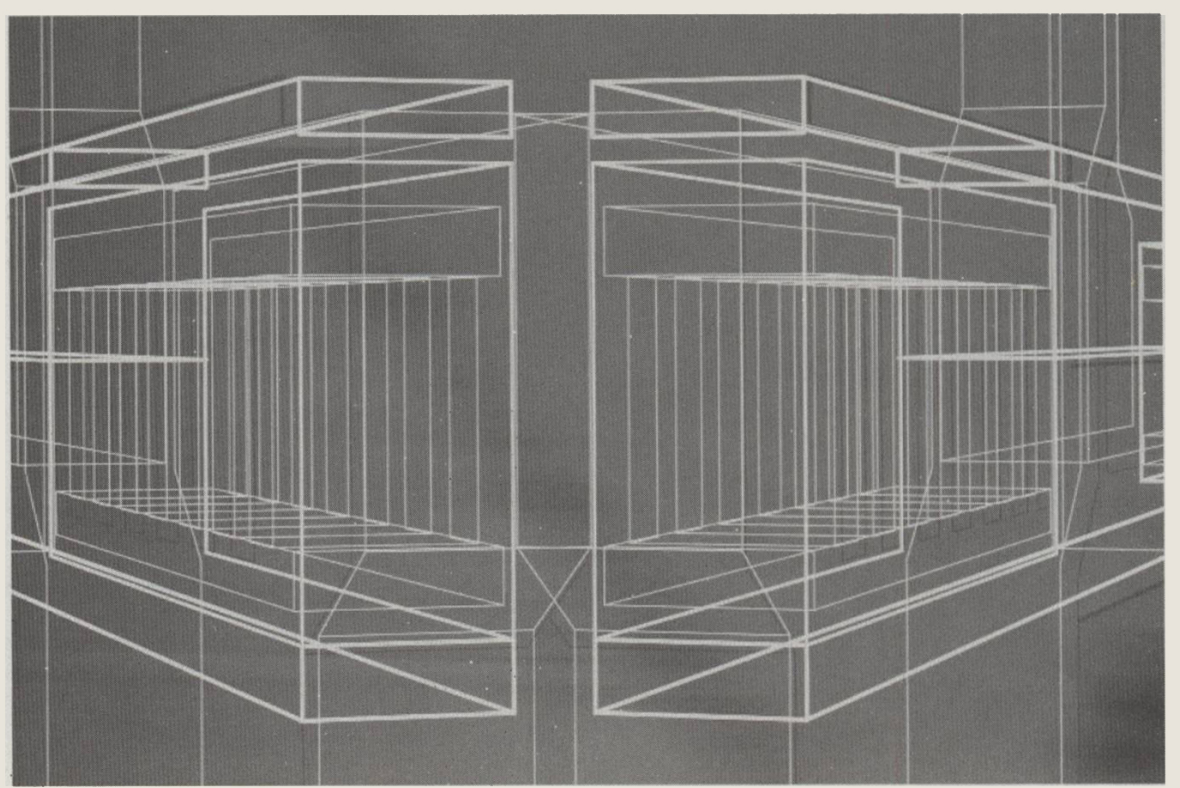

Subject coverage includes:

$\begin{array}{lll}\text { - Advertising } & \text { - Education } & \text { - Interior design } \\ \text { - Architecture } & \text { - Environmental design } & \text { - Jewellery } \\ \text { - Book design } & \text { - Exhibition design } & \text { - Metalwork } \\ \text { - Calligraphy } & \text { - Fashion } & \text { - Packaging } \\ \text { - Ceramics } & \text { - Fibre arts } & \text { - Photography } \\ \text { - Computer graphics } & \text { - Furniture } & \text { - Structural design } \\ \text { - Crafts } & \text { - Glass } & \text { - Textiles } \\ \text { - Design for disability } & \text { - Graphic design } & \text { - Theatre design } \\ \text { - Design history } & \text { - Illustration } & \text { - Typography } \\ \text { - Design theory } & \text { - Industrial design } & \text { - Vehicle design }\end{array}$

